\title{
Use of biodigesters, cisterns and desalinators: social technologies as sustainable alternatives of coexistence with the Semiarid.
}

Utilização de biodigestores, cisternas e dessalinizadores: Tecnologias sociais como alternativas sustentáveis de convivência com o semiárido.

\section{Juan Carlos Alvarado Alcócer', Olienaide Ribeiro de Oliveira Pinto", Maria Dasdores Gonçalo Costa"', Maria Elanny Damasceno Silva'v, Jangirglédia de Oliveirav, Aluísio Marques da Fonsecavi}

\section{Abstract}

The work studies biodigestors, cisterns and desalinizers as sustainable alternatives to coexist with the semi-arid region, seeking to understand how it is possible to benefit rural populations from the production and use of social technologies. The methodology consists of bibliographical surveys from case studies and field studies on the use of these technologies in the semi-arid region. Experiences of use were selected in the municipalities of Barreira, Ocara, Redenção and Ibaretama in the state of Ceará. In the biodigestor is contextualized the most used models at Brazil and the semiarid, with emphasis on the models adopted in the municipalities of Barreira, Ocara and Redenção. In addition, to address the importance of the use of biogas and biofertilizer. In the cisterns, the types that were used in the semi-arid region were verified and the experience of the tanks program in the municipality of Ibaretama was mentioned. In the case of desalinators, the relevance of desalination systems for populations living in water scarcity was discussed, identifying the current equipment panorama installed in Barreira. As results, it was observed that it appears as a solution to meet the basic needs of populations with water supply. Biogas can be used to replace cooking gas and biofertilizer as fertilizer for plants. To do so, it requires greater attention from the public power and active involvement of the population. It is concluded that these technologies are feasible, adaptable to rural property, simple and low cost, since they tend to solve social and structural problems, besides generating income and quality of life for the populations.

Keywords: Semi-arid Regions; Drought; Organic Waste; Social Inclusion; Sustainability

\section{Resumo}

O trabalho estuda os biodigestores, cisternas e dessalinizadores como alternativas sustentáveis de convivência com o Semiárido buscando a compreensão de como é possível beneficiar as populações rurais a partir da produção e utilização de tecnologias sociais. A metodologia consiste em levantamentos bibliográficos a partir de estudos casos e de campo sobre a utilização dessas tecnologias na região semiárida. Selecionou-se experiências do uso nos municípios de Barreira, Ocara, Redenção e Ibaretama no estado do Ceará. No biodigestor contextualizou os modelos mais utilizados no Brasil e no Semiárido, com destaque para os modelos adotados nos municípios de Barreira, Ocara e Redenção. Além de, abordar sobre a importância do uso do biogás e do biofertilizante. Nas cisternas, verificou-se os tipos que são empregados no Semiárido e citou a experiência do programa de cisternas no município de Ibaretama. No caso dos dessalinizadores, abordou a relevância dos sistemas de dessalinização para as populações que vivem em situação de desabastecimento hídrico, no qual, identificou o panorama atual dos equipamentos implantados em Barreira. Como resultados, observou-se que surgem como uma solução para atender as necessidades básicas das populações com fornecimento de água. Já o biogás pode ser usado para substituir o gás de cozinha e o biofertilizante como adubo para plantas. Para tanto, requer maior atenção do poder público e envolvimento ativo da população. Conclui-se que essas tecnologias são viáveis, adaptáveis a propriedade rural, simples e de baixo custo, pois tendem a resolver problemas sociais e estruturais, além de gerar renda e qualidade de vida as populações.

Keywords: Regiões Semiáridas; Estiagem; Resíduos Orgânicos; Inclusão Social; Sustentabilidade

\footnotetext{
Universidade da Integração Internacional da Lusofonia Afro-Brasileira (UNILAB) - jcalcocer@unilab.edu.br

Universidade da Integração Internacional da Lusofonia Afro-Brasileira (UNILAB) - agron.olienaide@gmail.com

II Universidade da Integração Internacional da Lusofonia Afro-Brasileira (UNILAB) - dasdoresgoncalocosta@gmail.com

v Universidade da Integração Internacional da Lusofonia Afro-Brasileira (UNILAB) - elanny13@gmail.com

Universidade da Integração Internacional da Lusofonia Afro-Brasileira (UNILAB) - jg.jangir@gmail.com

V' Universidade da Integração Internacional da Lusofonia Afro-Brasileira (UNILAB) - aluisiomf@unilab.edu.br
} 


\section{Introdução}

The Brazilian semi-arid region covers an area of $982,566 \mathrm{~km}^{2}$, with some 22 million inhabitants, concentrating the Brazil's rural population majority (IBGE, 2016). This region presents follow characteristics: near to aridity, rainfall scarcity and the restricted rainwater storage system (BAPTISTA; CAMPOS, 2014). Water utilization is limited by a typical situation in the Northeastern region: the high salt content. A great part of the area is located over crystalline rocks and the underground contact for a long time between water and this type of rock favors its salinization (COSTA; ALCÓCER; PINTO, 2018)

The idea of coexistence with the Semiarid is a proposal for the confrontation of economic and socioenvironmental issues of the region (SOUSA et al., 2017). Social technologies are shown as prosperous, accessible and low-cost options, adaptable to operation and maintenance of rural properties that allows the solution of structural problems of the most excluded layers of society. From these technologies can be found answers to themes such as education, environment, energy, food, housing, water, labor and income, health, among others. It's necessary to use two fundamental premises for its propagation: the participation of people in the communities and sustainability in the proposed solutions (COSTA et al., 2013).

The needs of the coexistence with the semi-arid region reality impose to populations and organizations the integration, to suggest a new development model for the region. Structured around the "Living with the Semi-Arid" movement, this model is considered an important instrument for achieving the sustainable development of the Brazilian semi-arid region (SOUSA et al., 2017).

The coexistence with the semi-arid region shows a change in the perception of the territorial difficulty and makes it possible to rescue and build relations of coexistence between human beings and nature, with the aim to improving the life's quality of rural families (CONTI; SCHROEDER, 2013). Therefore, the use of social technologies such as biodigester, cisterns and desalinator are potentially adequate with the aim of diminish the basic social difficulties and enable the sustainable coexistence with the semi-arid mainly for the rural populations (TOLLER, 2016).

In this context it is of utmost importance to include technologies that can alleviate the social difficulties of several communities living in regions with prolonged drought, in places where water use is limited by their high concentration of salts and where there is animal waste and vegetable) produced in rural properties. The aim is to develop the income's generation improving the quality of life of the farmers, social well-being and promoting the coexistence with the semi-arid (SILVA et al., 2018).

The main objective of this work was to study the use of biodigesters, water captation cisterns and desalinizers as a sustainable alternative for coexist with the semi-arid region, seeking to understand how it is possible to benefit rural populations using social technologies without abdicating from vigilance and awareness to sustainability.
Methodology was a field work to obtain information on the use of the biodigester, cistern and desalinator in the semi-arid region. In the case of biodigestors, the use of the technology was analyzed in the Municipalities of Barreira, Ocara and Redenção, Massif de Baturité, Ceará. In the cisterns, their impacts on the use by rural families in the city of Ibaretama, Sertão Central, Ceará, were verified. For the desalinators, a field study was carried out by means of a survey, in which the current situation of desalination systems was reported in several localities in the municipality of Barreira.

\section{Biodigester as alternative technology to coexist with semi-arid}

The biodigester is an equipment that presents several applications, among them the environmental impacts minimization caused by incorrect organic residues destination generated in many rural properties, reuse of the waste that would be discarded without benefit allowing the production of biogas. In this biological process, there is a growth of microorganisms that depend on appropriate conditions of humidity, temperature and acidity, resulting in the formation of biofertilizer and gaseous products such as methane and carbon dioxide that compose the biogas (SECHINEL, 2011; ALCÓCER et al., 2014).

It is possible to observe that the biodigester allows to give a destination to the wastes that would pollute the environment, producing biogas and biofertilizer, which can be used for direct burning, electric energy production and as organic fertilizer in the rural property plantations. Due to this diversification of functions, the biodigester was compared to a mixture of basic sanitation plant, oil well and fertilizer plant (BARREIRA, 2011).

Despite the biodigestor's acknowledged importance in the transformation of organic waste (biomass) into energy and heat, studies indicate that few properties have incentives to invest in the implantation of this technology, and biomass is discarded without any type of treatment being carried out. Adapted to locality reality, the results of the process of biodigestion occurring within the biodigester by anaerobic bacteria have been significant, since they contribute to adequate waste disposal, besides contributing to the generation of energy and heat, reducing costs in rural properties (SILVA; FRANCISCO, 2010). In Table 1, it is showed the main advantages observed with the implantation of biodigesters in rural properties.

There is a great variety of models for the biodigester facility, but it is an old technology, consisting of a closed chamber constructed of masonry, concrete or other materials. The closed chamber is the place where the chemical reactions of degradation of the biomass occurs. Inside it, is produced the biogas by the anaerobic digestion (fermentation). This chamber must be fed through an inlet and has an outlet to withdraw the biogas and another for the biofertilizer (BARREIRA, 1993; FRIGO et al., 2015; CALDEREIRO, 2015).

The process of anaerobic digestion that takes place within the biodigestor also favors the improvement of the 
Table 1 - Main advantages with the implantation of biodigesters in rural properties

\begin{tabular}{ll}
\hline \multicolumn{1}{c}{ Main advantages of the biodigester } \\
\hline - & Sustainable alternative treatment of animal waste and the remains of agricultural plants; \\
- & There is no consumption of electricity; \\
- & Small area demand for the installation; \\
- $\quad$ Production of biogas and biofertilizer; \\
- Improvement of soil physical and chemical characteristics; \\
- Conservation of the environment. \\
\hline Source: Silva e Francisco (2010)
\end{tabular}

hygiene conditions for the animals and handlers due to the daily cleaning of the facilities to collect the manure. Appropriate treatment of manure reduces contamination and the proliferation of flies and mortality of animals, thus increasing production as well as product quality (ALVES et al., 2010).

The models of biodigestors commonly found in the literature are Indian, Chinese, Canadian and by batch. The rural property features are necessary for to choice a proper biodigester type. Each biodigestor is suitable for the different residues obtained in the rural environment, being able to operate with continuous loads, when feeding the biodigestor daily, or in batch, when the waste is placed in the biodigester and left for a certain period (FRIGO et al., 2015).

\subsection{Biodigester models}

Biodigesters in batch (Figure 1); add the organic residue at one time in the anaerobic digestion chamber. Subsequently, the biodigestor is hermetically sealed, favoring anaerobic digestion. The gas produced is stored in the digestion chamber or in a gasometer coupled to it. After completing the entire biodigestion process, the biofertilizer generated is removed and a new waste load is added. It is a model indicated when there are residues in large quantities in a short time, as with chicken beds, where there's not daily residue in the property, but at the end of bird growth (ALVES et al., 2010).

Continuous flow biodigesters commonly are Indian, Chinese and Canadian. In these types of biodigesters, there is a continuous load of waste and a constant production of biofertilizer and biogas. This model has a waste inbox and a biofertilizer outlet and the substrate itself in the biodigester is responsible for part of the system seal. It is indicated when rural producer possesses a quantity of residues produced more consistently in the property (swine and bovine waste, for example) and labor to carry out the daily loads (GONÇALVES et al., 2018; FRIGO et al., 2015).

The Indian biodigester is characterized by the fact that it has a bell, a kind of lid, like a gasometer, which can be immersed in the biomass in fermentation, and its structure consists of a central wall that divides the fermentation tank in two chambers, allowing the biomass to circulate inside the fermentation chamber (DEGANUTTI et al., 2002). In this type of biodigester, the fermentation process happens faster, because it takes advantage of the soil

Figure 1- Biodigesters in batch: Homemade biodigesters made of $20 \mathrm{~L}$ water bottle, at International Integration of Lusophony Afro - Brazilian University (UNILAB by its name in portuguese), Redenção, Baturité Massif, Ceará

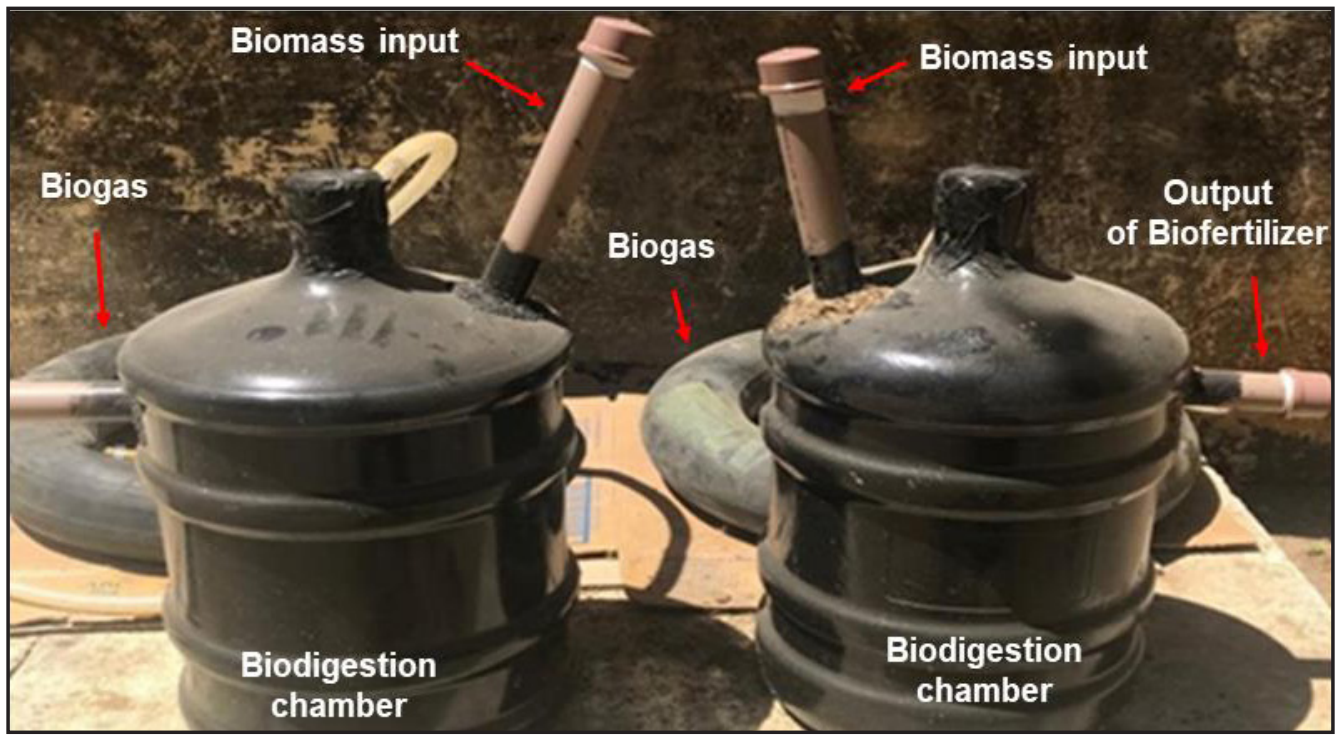

Source: Authors (2019) 
temperature that is slightly variable, favoring the action of the anaerobic microorganisms (BARICHELLO, 2010).

Figure 2 shows an example of an Indian model biodigester constructed by a small farmer in the Brazilian Northeastern Semi-arid. The biodigester was built in the community of Uruá, Barreira, Baturité massif, Ceará, to destine pork waste, since the breeding of these animals caused fetid odors at neighboring properties and environmental damages. The rural property has approximately one hectare and the biodigester was constructed with the low cost materials, being a part of the material, acquired in the rural property and the other in the local commerce of the municipality (SILVA et al., 2018).

The installation of the biodigester on the small property solved the swine manure residues disposal and avoided environmental damages. Daily the farmer sanitizes the bay where the animals are, and the waste (biomass) is sent directly to the loading box of the biodigester through a pipe. The farmer reports that currently, in addition to not causing further inconvenience to neighbors, still produce the biogas that replaced the LPG gas (Liquefied Petroleum Gas) for to cooke food and the biofertilizer used in the plants of the property, increasing their income and improving their family's quality of life.

Figure 2 - Indian biodigester, community of Uruá, municipality of Barreira, Baturité Massif, Ceará

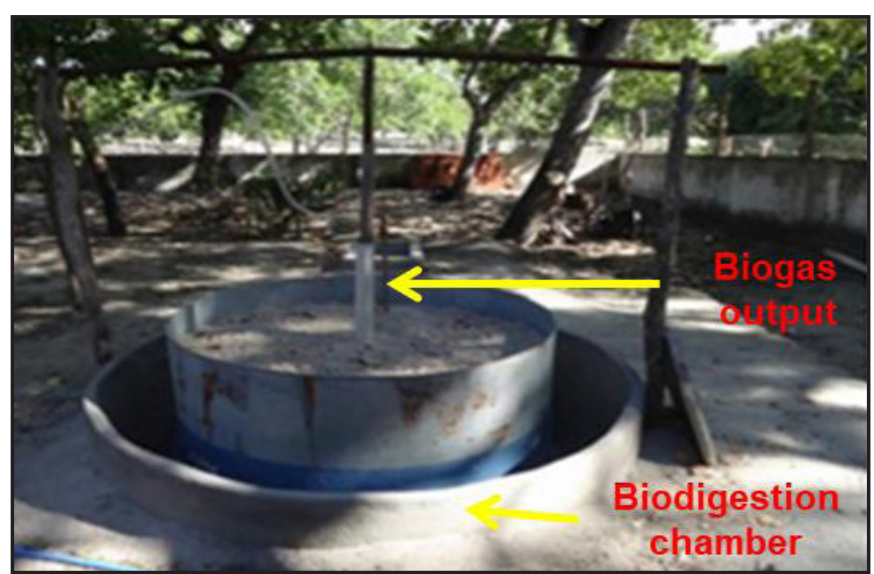

Source: Silva et al. (2018)
According to Silva Brazil, especially in the semi-arid region, has favorable conditions for the installation of biodigesters and consequently for the production of biogas and biofertilizer, lacking only governmental incentives and society organization to disseminate their use and exploration (SILVA et al., 2018).

Another example of an Indian biodigester built to serve rural communities at northeastern semi-arid region is in the "Lagoa do Serrote" town in the Ocara's municipality, Baturité Massif, Ceará. This equipment after their installation promoted several benefits for people using it (Figure 3). In this locality, there are three Indian biodigesters at Denir settlement. The seven settlements in the municipality met with the purpose of choosing a technology to coexist with the semi-arid region in the agroecological perspective and they selected the biodigester (PINTO et al., 2018).

The biodigester has a capacity of $40 \mathrm{~kg}$ of biomass (fresh bovine manure), being composed of biodigestion chamber, cargo box (biomass input); (biofertilizer outlet) and a biogas outlet piping that is connected directly to the farm house's kitchen stove for to cooke food. Biogas is produced daily and is enough to supply the LPG gas needs for two families approximately, each composed by five members. The biofertilizer is used in the garden to produce various vegetables (chives, coriander, pepper, lettuce, cabbage, etc.) and some fruit trees (banana, papaya, coconut, lemon tree, etc.), thus abstaining from financial expenses with fertilizer for plants. The family that benefited from the construction of this biodigestor reports that biogas and biofertilizer produced are used constantly. According to the farmers the use of this technology is being very useful mainly because they do not need to buy LPG cooking gas and use biogas in the cooking of foods favoring the domestic economy of the family contemplated with the equipment (PINTO et al., 2018).

The Chinese model biodigester (Figure 4) is a single piece model, built in masonry and buried in the ground, to occupy less space. This model has a reduced cost in relation to the others, because its dome is made in masonry. The Chinese model is more rustic. It operates normally with high pressure, which varies according to

Figure3 - Indian biodigester in the Serrote Lagoa, Ocara municipality, Baturité Massif, Ceará

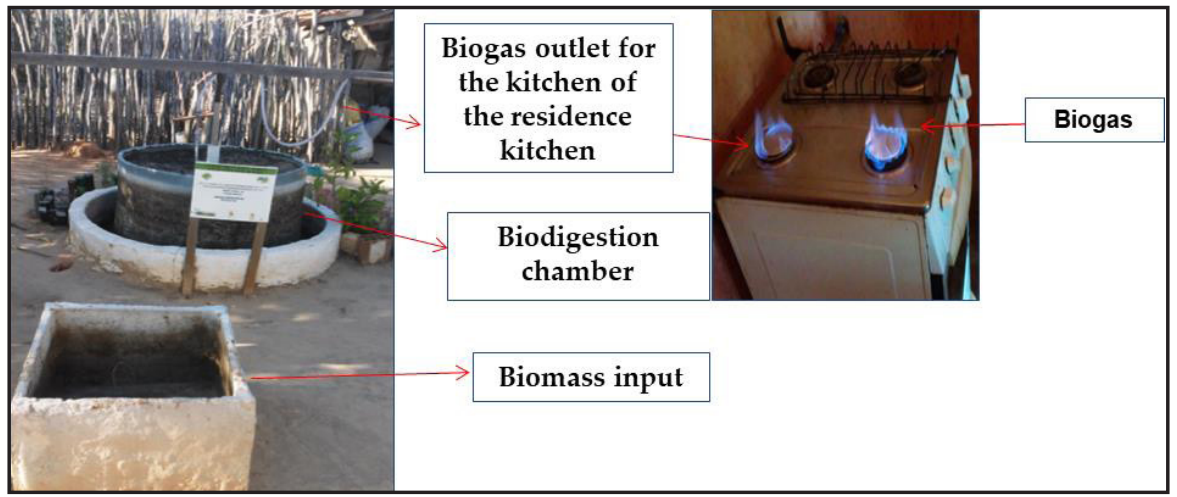

Source: Adapted from Pinto et al. (2018) 
Figure 4 - Chinese biodigester scheme

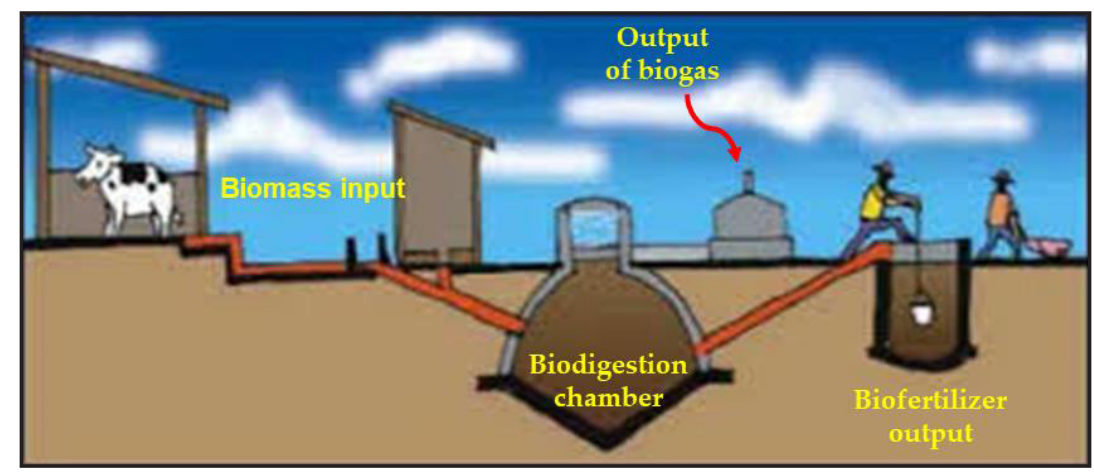

Source: Adapted from Eco-Village (2018)

the production and consumption of biogas; there is no possibility of having a regulating chamber, which would allow it to work with low pressure (BARICHELLO, 2010). In this type of biodigester is dispensed the use of gasometer, because it has a masonry structure and would cause problems such as the leakage of biogas, since it does not have a partition in the biodigestion chamber as in the Indian model (FRIGO et al., 2015).

Another widely used biodigester is the Canadian model (Figure 5). It presents a masonry load box with a width greater than depth, and therefore has a larger area of exposure to the sun, which allows a large biogas production (CASTANHO; HARRUDA, 2008). Usually, this type of biodigestor has an underground fermentation chamber lined with plastic canvas. It also has a top blanket to hold the biogas produced, to form a storage bell. It also has an outlet box where the effluent is released (biofertilizer), a register for the exit of the biogas and a burner, which is connected to the biogas output register (PEREIRA et al., 2009). Figure 5 shows another practical situation of the use of the Canadian model biodigester technology in the coexistence with the semi-arid region. It is a medium production pig farm located in the municipality of Redenção, Baturité Massif, Ceará (PINTO et al., 2018).

Figure 5 - Canadian biodigester in the municipality of Redenção, Baturité Massif, Ceará

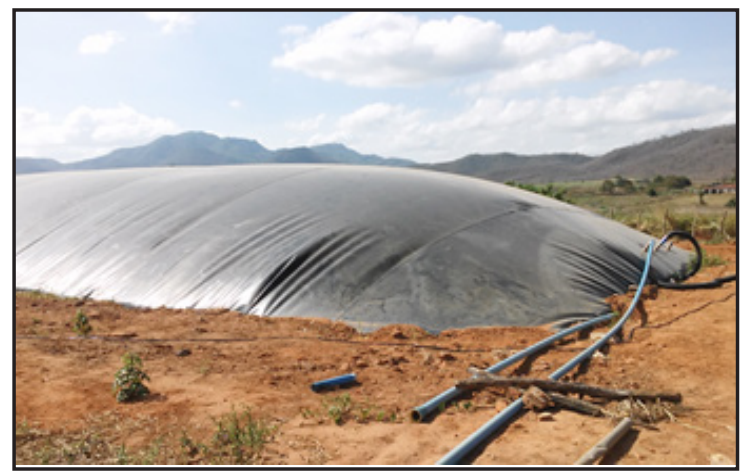

Source: Pinto et al. (2018)

The biodigester facility is for the pig waste reutilization, generating organic fertilizer to be used in the fertilization of the forage plants that serve to feed the animals and the biogas to be transformed into electric energy. The biodigester has a capacity of $200 \mathrm{~m}^{3}$, two exits, one for biogas and one for biofertilizer that is stored in two stabilization ponds (Figure 5). This biodigester facility is for to solve an environmental problem caused by swine manure. The farm owner reports that he reduced his financial costs with the installation of the biodigester (PINTO et al., 2018).

The most widespread models in small rural properties in the Brazilian northeastern semi-arid region are Indian and Chinese model biodigesters, since they are easy to install and use low price materials, often found in rural properties and in local commerce (OLIVEIRA et al., 2016).

At Brazil, there are some companies responsible for selling biodigestors kits of various proportions with installation manuals and even with electric generator included. However, the basic structure of the biodigestor is something simple and can be easily developed using recyclable material explained in Figure 1, thus being an accessible and flexible method of discarding organic residues (SILVA et al., 2018; OLIVEIRA et al., 2016). The main characteristics for the biodigesters are shown in Table 2.

Table 2 - Models of biodigesters and its elements.

\begin{tabular}{|c|c|c|}
\hline Models & Load stream & Main elements \\
\hline Indian & Continuous & $\begin{array}{ll}\text { - } & \text { Biomass Reservoir; } \\
\text { - } & \text { Biofertilizer reservoir; } \\
\text { - } & \text { Dome of gas; } \\
\text { - } & \text { Fermentation tank } \\
\end{array}$ \\
\hline Canadian & Continuous & $\begin{array}{l}\text { - } \quad \text { Biomass pond; } \\
\text { - } \quad \text { Gas storage canvas; } \\
\text { - Biofertilizer reservoir. }\end{array}$ \\
\hline Batch & Discontinuous & $\begin{array}{l}\text { - } \quad \text { Brewer; } \\
\text { - } \quad \text { Biofertilizer reservoir. }\end{array}$ \\
\hline Chinese & Discontinuous & $\begin{array}{l}\text { - } \quad \text { Biomass Reservoir; } \\
\text { - } \quad \text { Biofertilizer reservoir; } \\
\text { - } \quad \text { Dome of gas (masonry); } \\
\text { - } \\
\quad \text { (masormentation tank } \\
\text { (masonr. }\end{array}$ \\
\hline
\end{tabular}


urce: Shubeita et al. (2014)

\subsection{Biogas and biofertlizer}

Biogas is a renewable and clean fuel and can replace LPG cooking gas; its burning does not release smoke and leaves no residue in the pots. The biogas can be used in: stoves, lamps, campanula, Chocadeiras, diverse dryers, internal combustion devices, moto-bomba sets, electrical energy generators (ALVES et al., 2010). Despite being found naturally in environments such as swamps and dark sludge, biogas can be produced artificially using different types of organic matter, from animal manure to agricultural waste, sewage sludge and urban waste (JUNQUEIRA, 2014).

Biogas is a mixture of hydrocarbons (chemical compounds formed by Carbon and Hydrogen such as Carbon Dioxide $\left(\mathrm{CO}_{2}\right)$ and Methane $\left(\mathrm{CH}_{4}\right)$ gas (ROYA et al., 2011). The proportion of biogas components is shown in Table 3.

Table 3 - Biogas components

\begin{tabular}{lc}
\hline Components & Percentage (\%) \\
\hline Methane $\left(\mathrm{CH}_{4}\right)$ & $55-70$ \\
Carbon dioxide $\left(\mathrm{CO}_{2}\right)$ & $25-45$ \\
Nitrogen $\left(\mathrm{N}_{2}\right)$ & $<3$ \\
Hydrogen $\left(\mathrm{H}_{2}\right)$ & $<2$ \\
Oxygen $\left(\mathrm{O}_{2}\right)$ & $0-0,1$ \\
Hydrogen Sulfide $\left(\mathrm{H}_{2} \mathrm{~S}\right)$ & $<1$ \\
\hline
\end{tabular}

Source: Roya et al. (2011)

Is the methane percentage that gives biogas a high calorific value, ranging from 5,000 to $7,000 \mathrm{kcal}$ per cubic meter. This variation is due to its purity. Highly purified biogas can reach up to $12,000 \mathrm{kcal}$ per cubic meter. It is interesting to compare the heat capacity of biogas with other energy sources found in nature. Table 4 shows the capacity of $1 \mathrm{~m}^{3}$ biogas generation of various types of biomass (BARREIRA, 2011).

Table 4 - Capacity of $1 \mathrm{~m}^{3}$ biogas generation.

\begin{tabular}{lc}
\hline Organic waste & Amount \\
\hline Cow Shed & $25 \mathrm{~kg}$ \\
Swine manure & $12 \mathrm{~kg}$ \\
Dry Chicken Spit & $5 \mathrm{~kg}$ \\
Vegetable waste & $25 \mathrm{~kg}$ \\
Garbage & $20 \mathrm{~kg}$ \\
\hline Source: Barreira(2011)
\end{tabular}

Analyzing data from Table 4 it is observed that in the case of swine manure as raw material, the production of $1 \mathrm{~m}^{3}$ of biogas requires only $12 \mathrm{~kg}$ of swine manure. Therefore, if a pig produces $2.25 \mathrm{~kg}$ of waste/day, it takes about 5 animals to produce $12 \mathrm{~kg}$ /day of waste with $1 \mathrm{~m}^{3}$ of biogas production. So the installation of biodigestor technology is feasible and should be made available to farmers who have small livestock farms, for example, pigs in the brazilian northeastern semi-arid region to disseminate the benefits of this social technology in the region.

The biofertilizer is one of the products resulting from the fermentation process of the organic matter (biomass) carried out within the biodigesters (VIEIRA et al., 2016). It is presented in two forms: liquid and pasty solid. The application of this biofertilizer to the soil improves the biological, chemical and physical qualities and provides a better penetration of the roots of the plants (BARICHELLO et al., 2011).

After the biodigestion process, the biofertilizer is already completely ready, when it leaves the interior of the biodigester, has no odor and is not polluting (ALVES et al., 2010). In addition, it causes the soil to absorb moisture better, resisting long periods of drought easily (BARICHELLO et al., 2011).

The biofertilizer can be disposed to the soil in natura or processed, dry and pelletized. In this way, it provides the maximum use of animal waste and the rest of agricultural crops, facilitating the process of adding value to rural property. With fertilization power, it favors the performance of the plants, making them more vigorous and productive, besides functioning in its liquid form as a natural defensive for some predatory species, being able to be used to replace chemical products (WESTRUP et al., 2015)

The water situation in the brazilian semi-arid region was initially treated by political measures to combat drought. The construction of dams marked this trajectory. Over time, this strategy changed due to the perception of non-solution of the effects of the droughts. The solution was to develop attitudes and techniques of coexistence with the semiarid. In this way, the A Million Cisterns Program (P1MC) was created to provide alternative supplies of domestic use, so that families would have their water needs fulfilled in months without rainy rainfall (ALMEIDA et al., 2016). The idea of combating drought has changed as governments and managers no longer see drought as a problem. The idea of coexistence with the semi-arid region enabled the first proposals for actions aimed at sustainability in the areas affected by this climatic phenomenon.

Regarding the trajectory of public water actions, Table 5 gives a brief summary of the actions aimed at reducing the effects of droughts, classifying as emergency measures, combating droughts and coexistence with the region.

Historically there are three periods of government actions in the semi-arid region: i) colonization of the region until the middle of the 20th century, in which after catastrophic water crisis forced the government to create tactics to combat droughts; ii) in 1950, the federal government analyzes the backwardness of the northeastern economy compared to the central and southern regions of the country and began 
Table 5 - Trajectory of the political actions to face droughts

\begin{tabular}{|c|c|}
\hline Measures & Works and actions \\
\hline Emergency & $\begin{array}{ll}\text { - } & \text { Food distributions } \\
\text { - } & \text { Land distributions } \\
\text { - } & \text { Camels importation } \\
\text { - } & \text { Water trants } \\
\end{array}$ \\
\hline Combating drought & $\begin{array}{ll}\text { - } & \text { Dams onstruction } \\
\text { - } & \text { Well implantation } \\
\text { - } & \text { Perimeter irrigated } \\
\text { - } & \text { Water desalination } \\
\text { - } & \text { Water transportation between basins }\end{array}$ \\
\hline Living with drought & $\begin{array}{ll}\text { - } & \text { Underground dams implantation } \\
\text { - } & \text { Tanks implantations }\end{array}$ \\
\hline
\end{tabular}

Source: Adapted from Machado et al. (2017)

to invest in irrigation and modern technologies for large estates without abandoning the methods employed to combat droughts; and iii) period of changes in the paradigm of public policies and the discussion between the different concepts of development (SILVA et al., 2016; SILVA, 2010).

An example of public policy acting for rural family's permanence is the Cisternas Program. Created by the Brazilian Semi-Arid Association (ASA) and jointly with private and public agencies elaborated the construction of cisterns for 16 thousand in the most affected regions by the droughts. The program aim was to enable the rainwater storage during periods of rainfall (NOGUEIRA, 2017).

According to Almeida, the consequence of accelerated cisterns construction in the semi-arid is visible changes in the daily routines of families, including a new landscape in the Northeast (ALMEIDA et al., 2016).

Of the main advantages obtained with the use of tanks is the water quality, low cost and easy access. However, water care is imperative, as there is the possibility of contamination by improper handling. Caution is important in cracking the structure of the technology, if it is not guarded and constructed as designed (NOGUEIRA, 2017).

Another inherent feature of the cistern, commonly used for rainwater harvesting, is to receive water from car kites replacing the lack of rainwater by water transported from other sources.

There were more proposals for technologies provided by public policy. Created in 2007 the Program One Land and Two Waters $(\mathrm{P} 1+2)$ that was implemented to assist in the planting of productive yards and raising animals for those who already had the initial technology of 16 thousand liters. P1 +2 is an extension of the Cisterns Program. Concomitant, another additional project followed up the actions, this time responsible for incorporating cisterns of 52 thousand liters in rural schools, the Program Cisternas at Schools (BRASIL, 2010). The following are several technologies developed for different needs and purposes for rural areas through the programs of tanks:

Domestic cisterns of 16 thousand liters: low cost P1MC work (Figure 6), made with precast concrete slabs, placed next to the dwellings and built by inhabitants of the communities or external, after being trained by the Cisternas Program. The families grant a counterpart contribution to aid in construction (ASA, 2018a). The tanks have manual pumps coupled for water suction, avoiding direct contact.

According to ASA data, 617,711 cisterns were built

Figure 6 - Cisterns for human consumption of 16 thousand liters ${ }^{1,2}$.
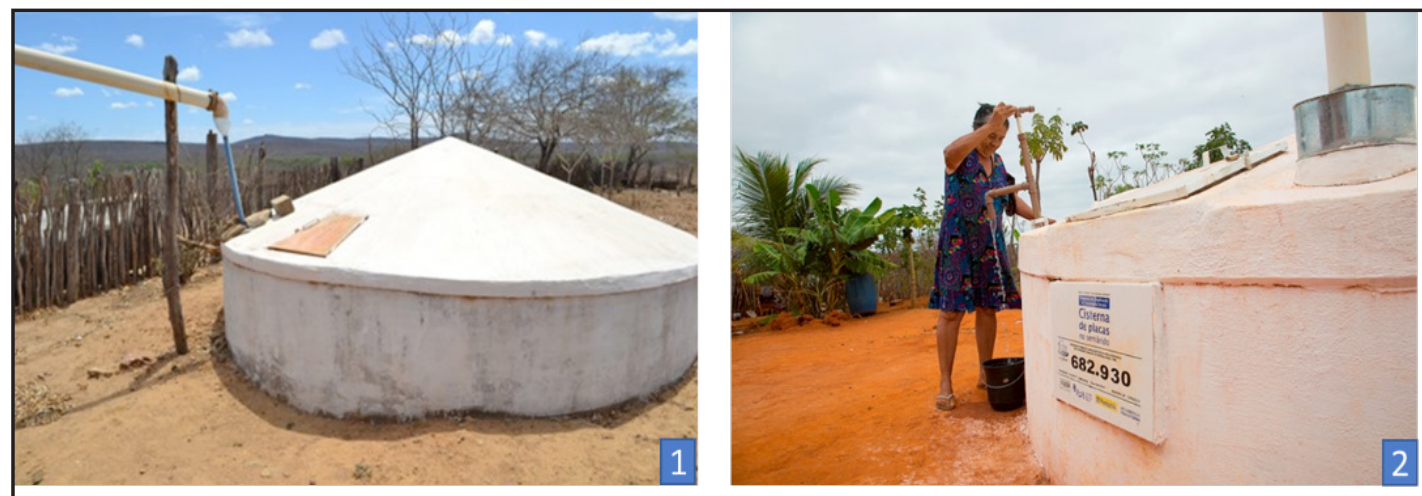
by mid-December 2018 for human consumption in semi-arid communities in the country, in addition to 102,358 technologies for food production and 6,841 school tanks (ASA, 2018c). Here are the social technologies currently available from $\mathrm{P} 1+2$ :

Stone tank: suitable construction for serranos sites with lajedos (wide cracks, natural holes or spaces of granites) that accumulate rainwater (FERREIRA et al., 2017). The amount of storage depends on the site constructed (Figure 7).

Boardwalk cistern: according to ASA the boardwa$\mathrm{lk}$ cistern collects rainwater through a $200 \mathrm{~m}^{2}$ cement boardwalk next to the cistern that has a capacity of 52 thousand liters (Figure 7). The pipes drain the water from the boardwalk to the technology. The utility of this water is useful for productive vegetable farms (fruit plants, vegetables and medicinal plants) and animal watering (ASA, 2018b).

Barreiro-trench: are long tanks and bottoms incorporated into the soil. Suitable for storing rainwater for any purpose of family production (Figure 8). It has capacity of up to 500 thousand /L, to the grantees also are delivered a submersible pump, electric cables, hose, a sheep and a bag of corn (CALIXTO JÚNIOR; SILVA, 2016).

Underground dam: intended for low areas near streams and corrégos. A ditch is excavated until the rock meets the ground, lined with plastic sheeting and covered (Figure 8). It has masonry bleeding to exit excess water, creating a wall that holds water underground, remaining soaked (ASA, 2018b).

Barraginha: It has between two and three meters of depth and diameter of 12 and 30 meters. Its shape resembles a shell and accumulates rainwater up to three months dampening the soil for longer. Their construction was in series one after another and as one bleeds, the next receives water and so on (Figure 9). It favors the formation of organic matter in the soil and has a mild climate around the area (ASA, 2018b).

Popular water pump: suitable for disused deep wells by manually extracting water by means of a flywheel (Figure 9). When you move it, suck large amounts of water. In wells with up to 40 meters withdraws up to one thousand liters in the time of one hour (ASA, 2018b).

An example of a study of the use of tank technology

Figure 7 - Stone $\operatorname{tank}^{3}$ and boardwalkcistern ${ }^{4}$.

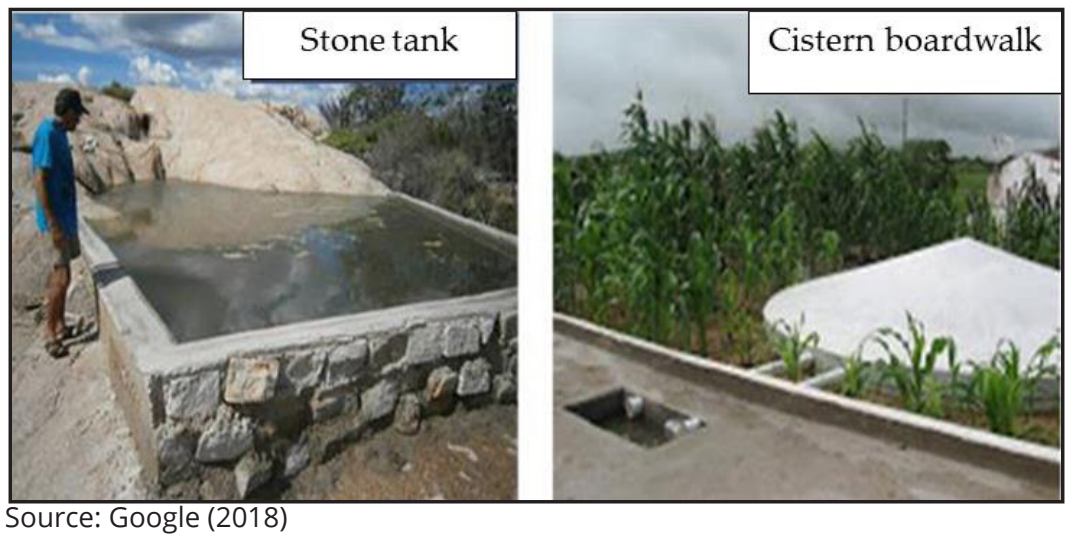

Figure 8 - Barreiro trench ${ }^{5}$ and underground dam $^{6}$

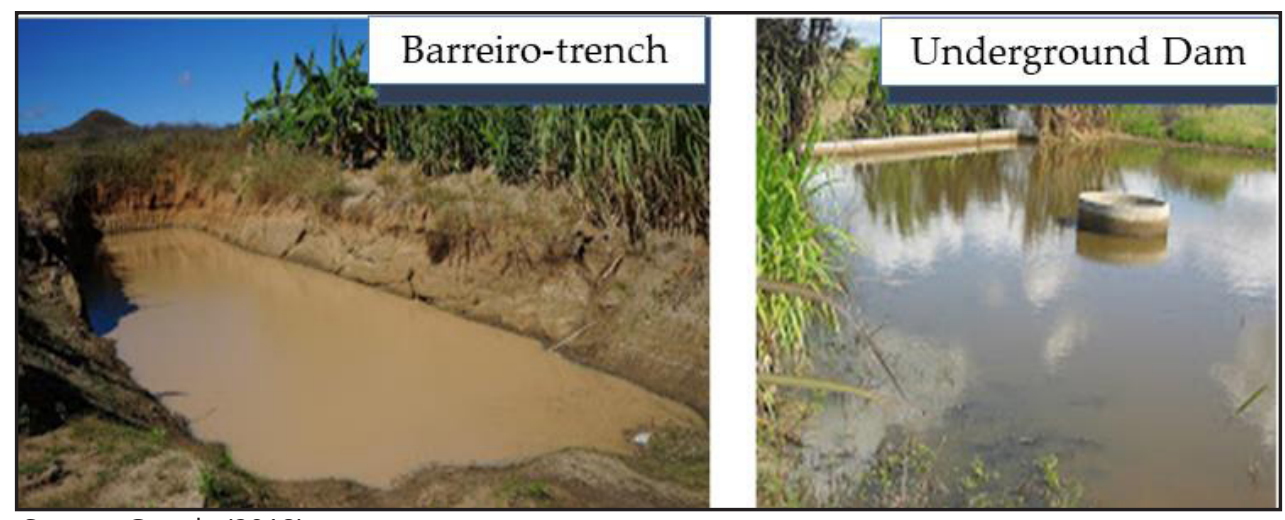

Source: Google (2018)

\footnotetext{
Available in: https://goo.gl/X4bABT. Acess in: dec. 202018.

${ }^{4}$ Available in: http://asaalagoas.blogspot.com/p/programas.html Acess in: dec. 202018.

Available in: https://goo.gl/zwjvjg. Acess in: dec. 202018.

Available in: http://asaalagoas.blogspot.com/p/programas.html Acess in: dec. 202018.
} 
Figure $9-$ Flood $^{7}$ cistern, barrage ${ }^{8}$ and popular water pump ${ }^{9}$.

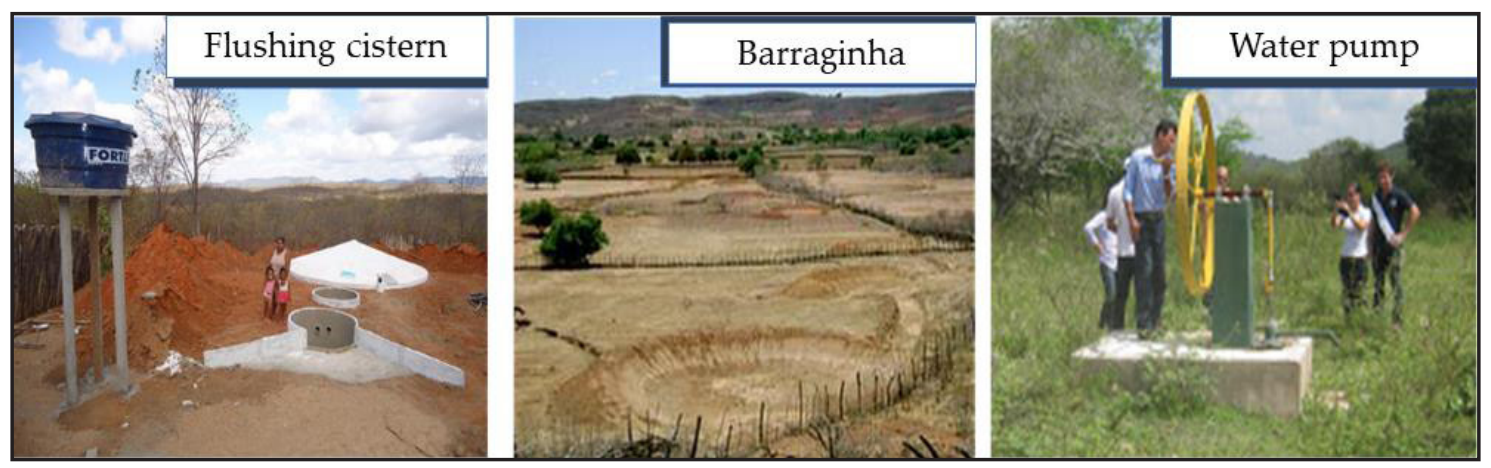

Source: Google (2018).

in the coexistence with the Semi-arid was carried out by Silva (2018) in which the impacts of the cisterns in the city of Ibaretama, Sertão Central, Ceará, were evaluated in the users perception. In this study, the author verified the impacts and satisfaction of users with the Cisternas Program in the municipality (Figure 10).

Figure 10 - Plate cisterns (A, B, C and D) in the municipality of Ibaretramas, Sertão Central, Ceará.

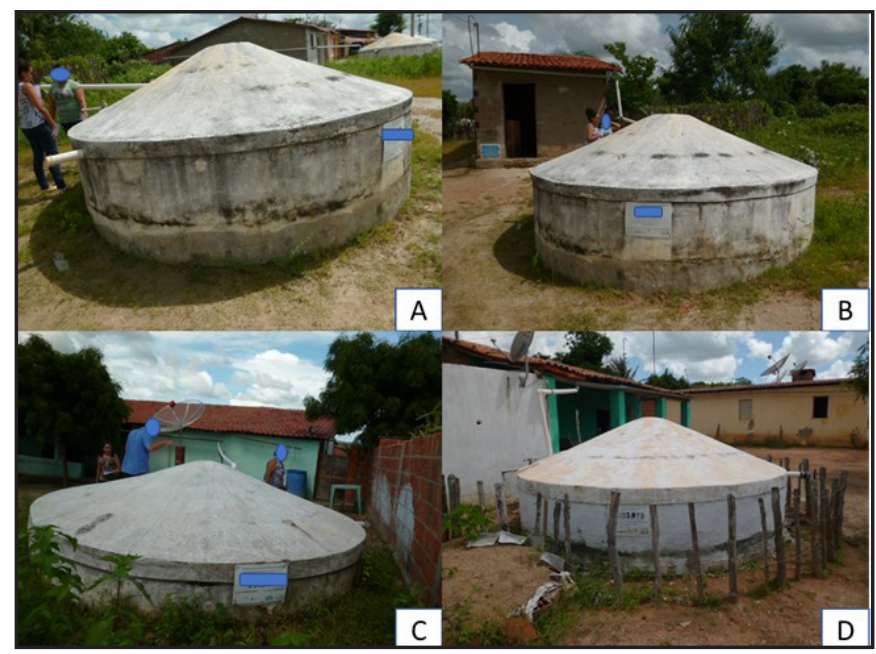

Source: Silva (2018)

In the Silva study (2018), it was observed that although the cistern structure and storage capacity fail to withstand prolonged droughts, families are satisfied with social technology. It also verified that the Cisternas Program did not obtain total effectiveness in reducing water limitations in the municipality, but there are other programs that act among themselves resulting in the guarantee of sustainability in the region.

The aforementioned technologies broaden the view of families that it is possible to remain in the hinterlands with greater perspectives of development in quality of life and economic growth when producing food and

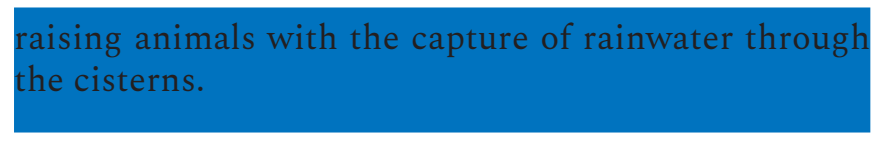

The Brazilian Northeast is characterized by semi-arid climate in which high temperatures, high evaporation rates and low rainfall rates make water very scarce. However, in many regions of the Northeastern Semi-arid, the use of water is limited by its high concentration of salts. Besides water being indispensable for life, it is also necessary for economic development and its scarcity is associated with the characteristic of the region. Therefore, desalination of brackish water from the subsoil in addition to providing potable water for human consumption also has the role of leveraging the economic development of the region (RUOTOLO et al., 2014).

The stigma of water scarcity in the Northeast, since there is a supply of fresh water, is characterized by the fact that $80 \%$ of river discharges occur in sectors occupied by $5 \%$ of the population, while the remaining $20 \%$ supply $95 \%$ of the quota. From the subsoil of the region, with no risk of water resources being drained, at least 19.5 billion $\mathrm{m}^{3}$ of water per year could be extracted. The use of this water, however, is limited by a typical problem of the water of the northeastern region: the salt content. Most of the area is located on crystalline rocks and the long underground contact between the water and this type of rock favors its salinization (MENEZES et al., 2012; SOARES et al., 2006).

In the Northeast, about $50 \%$ of the soils are formed by rocks of the crystalline basement (granites, gneisses, schists, etc.) of low water potential, corresponding to the states of Ceará, Rio Grande do Norte, Paraíba, Pernambuco, and east of Piauí, being considered areas with greater aridity (MME, 2009). The crystalline rocks present low values of porosity and primary permeability, which causes a slow circulation of the fluids and, therefore, a longer time of the percolated waters in the aquifers, with a greater sali- 
nization of the same ones (LUNA, 2016). Faced with this situation, the use of desalinizers is used to remove the salt from the water and make it drinkable for consumption in many regions of the northeastern Semi-arid region.

The process of hybridization of Technologies to coexist with the Brazilian semiarid arises as a possibility to integrate alternatives capable of minimizing the problem of fresh water scarcity and improving the living conditions of the population. Desalination of brackish or salt water becomes feasible in numerous regions of the planet where water availability is low. The processes of desalination can occur naturally through the hydrological cycle and mechanically through the systems implanted according to the specificity of each area there is in common the transformation into drinking water. Silveira et al. (2015) report that the act of collecting steam from salt water to cool them to quench thirst is probably as old as mankind, since it is a natural phenomenon, since fresh water present on the planet, at its highest percentage, originates from the evaporation of salt water, which then falls on the whole Earth in the form of atmospheric replacement, being responsible for the replacement of fresh water.

Literature in the Environmental Sciences mentions the water distribution in percentage terms. It is known that the planet is made up of $1 / 3$ of earth and $2 / 3$ of water, with about $97 \%$ of salt water and the $3 \%$ represent the amount of fresh water in the earth, and can be found in different forms and distributed in poles, groundwater, rivers and lakes (NUNES, 2018).

Considering the complexity of this temporal distribution and the aggravating factor in the water quality aspect, it is that at the beginning of the twentieth century with the institutionalization of water policies in the Northeast, the diffuse communities started to take advantage of the underground water of tubular wells as an alternative to the supply of d' water, although with salinity problems (NEVES, et al., 2016; BURITE; BARBOSA, 2018).

According to a report by the World Health Organization (WHO/UNICEF, 2017), about 844 million people do not have access to treated water. In the Brazilian semi-arid the demand for fresh water is one of the greatest obstacles for governments and society in relation to the water deficit that compromises food production and human and animal supply, the latter being a priority according to the Brazilian legislation on water resources. Population growth in these areas has required huge volumes of water. In this, region rocks of the crystalline basement (granites, gneisses, schists, etc) form about $50 \%$ of the soils. It is further aggravated by the fact that the soil of the country's depression is shallow, stony and with little drainage, affecting the quantity and groundwater quality (PINHEIRO et al., 2018).

Therefore, it is important to adopt the technology to extract salt from water, due to the considerable brackish and saline water availability, in order to guarantee access to quality water for human supply to the semi-arid population. It is therefore significant to know the classification of the waters in terms of salinity in accordance with art. 2 of National Environmental Council Resolution 357/2005 (CONAMA, 2005), which considers fresh water with less than $0.5 \mathrm{~g} / \mathrm{L}$ of salts, while the brackish water has between 0.5 and $30 \mathrm{~g} / \mathrm{L}$, while the saline water concentrates more than $30 \mathrm{~g} / \mathrm{L}$.

The desalination of brackish water from the subsoil in addition to providing drinking water for human consumption also has the role of leveraging economic development with the full use of drinking water and waste from the desalination process. Silveira et al. (2015), flash multi-stage distillation (FME), steam compression distillation (CVD), electrodíase and reverse electrodes (ED/ EDR), and reverse osmosis (OR). The author also states that the first desalination plant in the United States was installed in Florida in 1861. One of the poorest countries in water resources, Kuwait, had its desalination plant commissioned in 1914 (FWR, 2011).

That is, water desalination equipment has been installed at different times and in several countries for drinking water supply and irrigation. "Desalination is a process that has been practiced for more than 50 years in several arid and semiarid regions of the world" (BURITE; BARBOSA, 2018).

The implantation of water desalination equipment, through the reverse osmosis process, mainly in the semi-arid region of Brazil, is increasingly common. It is an electronic and hydraulic equipment performing the salt removal from water and other minerals with the utilization of a phusical - chemical process, producing potable water. The separation of salts present is due to the use of semipermeable membranes, producing a low salinity solution and a high salinity concentrate. Desalination occurs because water molecules diffuse through the membrane faster than salts and other compounds with higher molecular weight (SWITZERLAND, 2007). Thus, water produced in communities that have this system has reduced salt content and microbiological contaminants harmful to human health (PINHEIRO et al., 2018).

Desalination of brackish water can be a concrete tool for regional development in the semi-arid region of the Brazilian Northeast. Therefore, it is necessary to accelerate the implementation of these technologies in the regions most affected by the lack of water. The use of this technology ends up mitigating the precarious conditions of the water supply in the northeastern localities (CELLI, 2017).

In the state of Ceará, for example, there are 313 desalinators in different situations - functioning, deactivated, relocated, stopped and without information (SRH, 2017). The systems situation in rural communities produces some concern due to the lack of maintenance of the equipment and the negative impacts generated by the low use of the tailings and by the expressive portion of these that is thrown on the ground without any criterion or treatment. The example of a real situation was carried out a survey on the amount of desalination systems in the localities of the Barreira's municipality at Baturité Massif, Ceará. This study was carried out in both the urban and rural areas of the municipality in order to verify the desalination systems that were in operation and the inactive ones.

In this municipality, there were 18 equipment in 
16 locations between rural and urban: Angicos, Arerê, Batalha, Caiana, Crotá, Córrego, Cruz, Exu II, Grossos, Lagoa do Barro, Lagoa do Canto, and Lagoa do Meio, Mearim I, Pascoalzinho, Steel Tower and Uruá. There are 8 active desalination systems and 10 inactive systems, representing a percentage of $56 \%$ of the system deactivated and $44 \%$ active, according to Figure 11.

Figure 11 - Situation of desalinators in rural and urban communities in the municipality of Barreira, Baturité massif, Ceará.

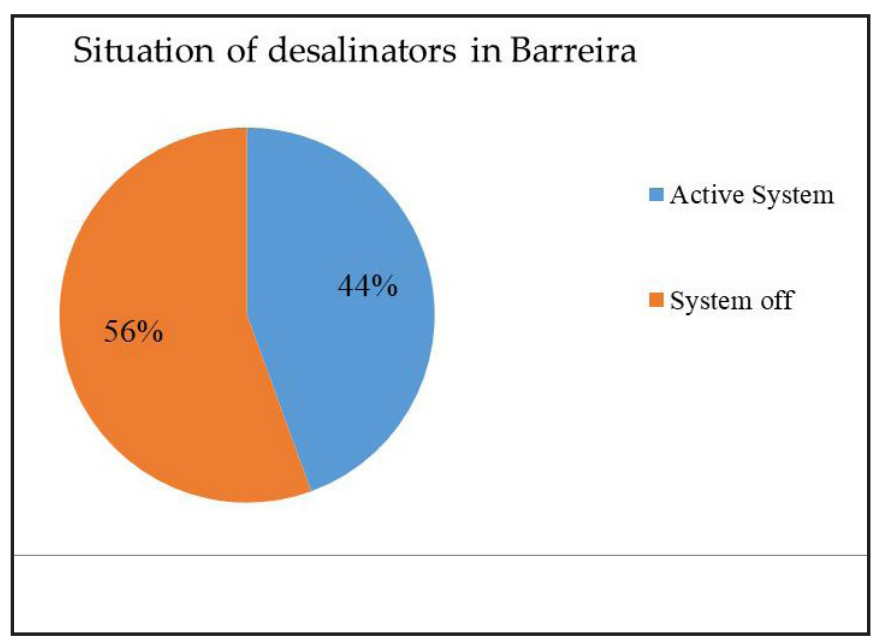

Source: Authors (2019)

That is, water desalination equipment has been installed at different times and in several countries for drinking water supply and irrigation. Desalination is a process that has been practiced for more than 50 years in several arid and semiarid regions of the world (BURITE; BARBOSA, 2018).

The scenario experienced by these communities explains issues that determine their situation in society; this emerges in the definition of establishing measures for the promotion of sustainable local development. In this perspective, the Fresh Water Program (PAD), coordinated by the Ministry of the Environment (MMA, 2012), is committed to ensuring access to drinking water for communities suffering from water shortages. Moreover, its purpose is:

To establish a permanent public policy of access to quality water for human consumption through the sustainable use of groundwater, incorporating environmental and social care in the management of desalination systems (MMA, 2012, p.35).

According to this thinking, Fiel and Schreiber (2017) uses the term sustainable with "the idea of sustainability and sustainable development, worrying about the future existence of natural resources to enable the continuation of human life." This fact directly reflects the need for water as an indispensable resource for life, a right guaranteed by the Constitution and defined by National Law 9.433 / 97.
Figure 12 shows the equipment for the stages of the desalination process of a desalinator installed in the Uruá Community, municipality of Barreira, Ceará.

Figure 12 - Equipment related to the stages of the desalination process in the Uruá Community. A) Reverse Osmosis Desinilator; B) Fountain with raw water reservoir; C) Well location; and D) Location point of the freshwater catch.

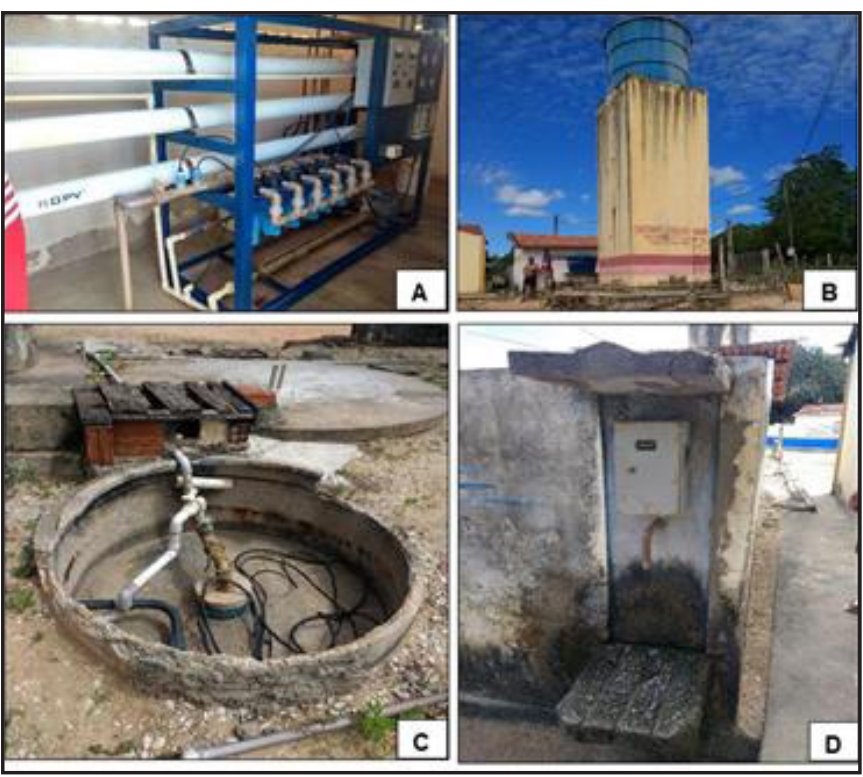

Source: Authors (2019)

It is important to highlight the importance of the integrated desalination system, with the present exercise of an autonomous and participatory management to operate the equipment and be self-sustaining.

\section{Conclusion}

The use of social technologies appropriate to the local reality, and the exploitation of the potential resources existing in the rural properties based on sustainable practices, are prevailing factors for the coexistence with the Semiarid, being able to generate income, improve the quality of life of farmers and social well-being.

Therefore, the use of social and alternative technologies such as biodigestor, cisterns and desalinator is a possibility of living with the semi-arid region based on the conscious and sustainable mentality, especially for the populations living in rural areas that suffer from the effects of prolonged droughts in and / or low rainfall index, as well as to reduce the waste of organic waste produced in rural properties, being able to be transformed into energy raw materials, as well as to generate income and improve the quality of farmers.

The application of technologies of coexistence with the semi-arid region, especially the biodigestor, cisterns and desalinator, has been characterized as a cultural perspective guiding a development, whose purposes are the 
improvement of living conditions and the promotion of citizenship, through initiatives socioeconomic and technological resources. In relation to this, although they are still in the process of consolidation, their proposals seek to contextualize the principles of sustainability, allowing the harmonization between social justice, ecological prudence, economic efficiency and political citizenship.

In this sense, the installation and monitoring of the operation of a biodigestor allows to affirm that its use brings benefits to rural properties. Especially because they are of simple construction, reasonably low cost and because they are dimensioned according to the quantities of residues existing in the rural property. Families that use the biodigester do not need to cut firewood or buy cooking gas, since biogas can be used for cooking food and the biofertilizer is used for fertilizing different plants. In addition, the fermentation of the organic matter inside the biodigestor prevents the methane expelled in the combustion to be released into the atmosphere promoting a sustainable activity for the environment.

In a region of water deficiency and in the context of climate change and the imminent water scarcity at the global level, the environmental dimension of the sustainability of rainwater harvesting and management policies is evident, as is the case of the cisterns described in this research.

The process of desalination of brackish or salt water by means of a desalinator is an option that contemplates isolated communities under conditions of water shortage, highlighting the prominent challenge in the sustainable use of groundwater, integrating innovative environmental and social practices in the management of desalination systems.

Social technologies present themselves as modern options and adapt to the small and medium-sized rural enterprise with a satisfactory cost-benefit that allows ease structural problems allowing the direct participation of the rural communities in the implantation process and contributing effectively in the development of the individual and collective consciousness of sustainability in the semi-arid region of the country.

\section{Referências}

ALMEIDA, C. L.; FALCÃO SOBRINHO, J. Convivência com o Semiárido através do uso de cisternas de placas. Revista Ambiente \& Educação, v. 21, n. 2, Edição Especial V CBEAAGT, p. 8-26, 2016. Available in: https://periodicos. furg.br/ambeduc/article/view/6410/4252. Acess in: dec. 182018.

ALCÓCER, J. C. A.; DUARTE, J. B. F.; M. J. CAJAZEIRAS; M. L. M. DE OLIVEIRA; R. G. DUARTE; ROCHA, Y. M. G. et al. Produzindo Biogás a partir de Resíduos de Frutas para Gerar Energia Elétrica. Revista SODEBRAS, v. 9, p. 113-116, 2014. Available in: http://www.sodebras.com. br/edicoes/n103.pdf. Acess in: jan. 212019.
Alves, E. E. N.; INOUE, K. R. A.; BORGES, A. C. Biodigestores: construção, operação e usos do biogás e do biofertilizante visando a sustentabilidade das propriedades rurais. II Simpósio Brasileiro de Agropecuária Sustentável, Universidade Federal de Viçosa - Viçosa/ mg, p.6-6, 25 set. 2010.

ASA - Articulação do Semiárido Brasileiro. Ações - P1MC. 2018a. Available in: http://www.asabrasil.org.br/acoes/ p1mc\#categoria_img. Acess in: dec. 92018.

ASA - Articulação do Semiárido Brasileiro. Ações - P1+2. 2018b. Available in: http://www.asabrasil.org.br/acoes/ p1-2. Acess in: 19 dec. 92018.

ASA - Articulação do Semiárido Brasileiro.. Semiárido vivo. 2018c. Available in: http://www.asabrasil.org.br/\#. Acess in: dec. 92018.

BARICHELLO, R. O Uso de biodigestores em pequenas e médias propriedades rurais com ênfase na agregação de valor: um estudo de caso da região noroeste do Rio Grande do Sul. 2010. 142 f. Dissertação (Mestrado) Curso de Centro de Tecnologia, Engenharia de Produção, Universidade Federal de Santa Maria, Santa Maria, RS, 2010.

BARICHELLO, R.; HOFFMANN, R.; CASAROTTO F. N.; BRONDANI, J. C.; BERNARDI, F. O uso de biodigestores em pequenas e médias propriedades rurais com ênfase na agregação de valor: um estudo de caso na região noroeste do Rio Grande do Sul. XXXI Encontro Nacional de Engenharia de Produção, Inovação Tecnológica e Propriedade Intelectual: Desafios da Engenharia de Produção na Consolidação do Brasil no Cenário Econômico Mundial. Belo Horizonte, MG, Brasil, 04 a 07 de outubro de 2011.

BAPTISTA, N. D. Q.; CAMPOS, C. H. A convivência no semiárido e suas potencialidades. 2014. Available in: <http://www4.planalto.gov.br/consea/comunicacao/ artigos/2014/a-convivencia-com-o-semiarido-e-suaspotencialidade>. Available in: 16 jan. 2019.

BARREIRA, P. Biodigestores. 3a edição. Ícone Editora, São Paulo, 2011.

BARRERA, P. Biodigestores. São Paulo, SP: Cone,1993.

BRASIL. Conselho Nacional do Meio Ambiente. Resolução CONAMA n $n^{357 / 2005}$. Dispõe sobre a classificação dos corpos de água e diretrizes ambientais para o seu enquadramento, bem com estabelece as condições e padrões de efluentes, e dá outras providências, 2005.

BRASIL, Ministério do Desenvolvimento Agrário. Plano Territorial de Desenvolvimento Rural Sustentável: Território do Sertão Central - MDA/SDT/UNITACE. Instituto Agropólos do Ceará. Fortaleza/CE, 2010. p. 262. Available in: http://sit.mda.gov.br/download/ptdrs/ ptdrs_qua_territorio080.pdf. Available in: dec. 162018. 
BURITI, C. O.; BARBOSA, H. A. Um século de secas: por que as políticas hídricas não transformam o semiárido brasileiro? 1ª edição: Chiado Editora, 2018. 427 p.

CALIXTO JÚNIOR, F.; SILVA, A. C. D. Sustentabilidade e políticas públicas de convivência com o Semiárido: um olhar sobre as tecnologias sociais no campo. Revista Casa da Geografia de Sobral, Sobral/CE, v. 18, n. 1, p. 44-62, jul. 2016. ISSN 2316-8056. Available in: http://uvanet. $\mathrm{br} / \mathrm{rcgs} /$ index.php/RCGS/article/view/285/279. Acess in: dec. 192018.

CALDEREIRO, G. M. Caracterização da digestão de resíduos agroindustriais em biodigestor de fluxo contínuo operado em escala real. 2015. 90 f. Dissertação (Mestrado em tecnologias ambientais), Universidade Tecnológica Federal do Paraná, Medianeira, 2015. Available in: http://repositorio.utfpr.edu.br/jspui/ handle/1/1277. Acess in: jan. 292018.

CELLI, R. Modelos de dessalinização e sua eficiência: comparativo entre tecnologias. Revista Gestão, Tecnologia e Inovação, v.1, n.1, 2017. Available in: http:// www.opet.com.br/faculdade/revista-engenharias/pdf/n1/ Artigo3-n1-Robson.pdf. Acess in: dec. 18 2018.ddxx xxx

CONTI, I. L.; SCHROEDER, E. O. (Org.). Convivência com o Semiárido brasileiro: autonomia e protagonismo social. Brasília, DF: IABS, 2013. Available in: http:// www. asabrasil.org.br/images/UserFiles/File/ convivenciacomosemiaridobrasileiro.pdf. Acess in: jan. 11 2018.

CONAMA - Conselho Nacional do Meio Ambiente. RESOLUÇÃO № 357, DE 17 DE MARÇO DE 2005. Publicada no DOU no 053, de 18/03/2005, págs. 58-63. Available in: http://www.mma.gov.br/port/conama/res/ res05/res35705.pdf. Acess in: dec. 182018.

CASTANHO, D. S.; ARRUDA, H. J. Biodigestores. VI Semana de Tecnologia em Alimentos. Universidade Tecnológica Federal do Paraná. Ponta Grossa, Paraná, Brasil, 2008.

COSTA, M. D. G.; ALCÓCER, J. C. A.; PINTO, O. R. O. Dessalinizadores: sistema de aproveitamento de rejeitos numa perspectiva participativa e sustentável no município de Barreira. In: XAVIER, A. R.; SILVA, M. S. L.; SILVA, F. A. L. (Org.) Meio ambiente, ensino de ciências, tecnologias Sustentáveis. Fortaleza: Imprece, 2018. p. 109-124.

COSTA, A. B.; RIBEIRO, M. M.; SERAFIM, M. P.; DIAS, R. B.; JESUS, V. M. B; DAGNINO, R. P.; BAGATTOLLI, C.; ABREU, K. D. R. Tecnologia Social e Políticas Públicas - São Paulo: Instituto Pólis; Brasília: Fundação Banco do Brasil, 2013. 284 p. Available in: http://www. polis.org.br/uploads/2061/2061.pdf; Acess in: jan. 162019.
CIRILO, J. A. Public Water Resources Policy for the Semi-Arid Region. Estudos Avançados, 63, n. 22, p. 6182, 2008. Available in: http://www.scielo.br/pdf/ea/v22n63/ en_v22n63a05.pdf. Acess in: jan. 122019.

DEGANUTTI, R. P.; M.C.J.P. PALHACI; M. ROSSI et al. Biodigestores Rurais: Modelo Indiano, Chinês e Batelada. Departamento de Arquitetura, Artes e Representações Gráficas, UNESP: (Universidade Estadual Paulista), Bauru, 2002. Available in: https:// www.agencia.cnptia.embrapa.br/Repositorio/ Biodigestores_000g76qdzev02wx5ok0wtedt3spdi71p. pdf. Acess in: jan. 162019.

FERREIRA, K. L. et al. Sustentabilidade e inovação, alternativas de convivência no semiárido mineiro: um estudo na mesorregião do Vale do Jequitinhonha. Anais do VI Simpósio Internacional de Gestão de Projetos, Inovação e Sustentabilidade - SINGEP, São Paulo, , 2017, p. 10. Available in: https://singep.org.br/6singep/ resultado/249.pdf. Acess in: dec. 162018.

FIEL, A.A.; SCHREIBER, D. Sustentabilidade e desenvolvimento sustentável: desvendando as sobreposições e alcances de seus significados. $1 \mathrm{Cad}$. EBAPE.BR, v. 14, no 3, Artigo 7, Rio de Janeiro, Jul./ Set. 2017. Available in: http://www.scielo.br/pdf/cebape/ v15n3/1679-3951-cebape-15-03-00667.pdf. Acess in: dec. 212018.

FRIGO, K. D. A.; FEIDEN, A.; GALANT, N. B.; SANTOS, R. F.; MARI, A. G.; FRIGO, E. P. Biodigestores: seus modelos e aplicações. Acta Iguazu, Cascavel, v.4, n.1, p. $57-65,2015$

FWR - FOUNDATION FORMWATER RESEARCH. A review of current knowledge desalination for water supplies. $2^{\circ}$ ed. 2011.35 p.

GONÇALVES, H. F. E.; LIMA, R. S.; WEISS, V. A. B.; MENEZES, V. S. O biodigestor como princípio de sustentabilidade de uma propriedade rural. Available in: http://www.catolicato.edu.br/portal/portal/downloads/ docs_gestaoambiental/projetos $20091 / 1$ periodo/O_ biodigestor_como_principio_de_sustentabilidade_de_ uma_propriedade_rural.pdf, Acess in: jan. 162018.

IBGE. Cadastro de municípios localizados na região Semiárida do Brasil. Rio de Janeiro, 2016. Available in: http://www.ibge.gov.br/home/geociencias/geografia/ semiarido.shtm?c=4. Acess in: jan. 162019.

JUNQUEIRA, S. L. C. D. Geração de energias através de biogás proveniente de estercp bovino: Estudo de caso na fazenda Aterrado. Rio de Janeiro. Universidade Federal do Rio de Janeiro. Agosto 2014. p. 7-15. 
LUNA, F. M. Desenvolvimento e testes de um dessalinizador solar com pré-aquecimento de água, 2016. 101f. Dissertação (mestrado em Energias Renováveis) - Programa de PósGraduação em Energias Renováveis, Universidade Federal da Paraíba, João Pessoa, Paraíba, 2016.

MACHADO, T. T. V.; DIAS, J. T.; SILVA, T. C. D. Evolução e avaliação das políticas públicas para a atenuação dos efeitos da seca no Semiárido Brasileiro. Revista Gaia Scientia, v. 11, n. 2, p. 84-103, jul. 2017. ISSN 1981-1268. DOI: 10.21707/gs.v11.n02a07. Available in: http://www.periodicos.ufpb.br/index.php/gaia/article/ view/31831/19308. Acess in: dec. 182018

MEnezes, J. S.; CAMPOS, V. C.; COSTA, T. A. C. Desenvolvimento de dispositivo caseiro para dessalinização de água salobra a partir de sementes de umbu (Spondias tuberosa Arruda Câmara). Química Nova, v. 35, n. 2, p.379-385, 2012.

MME - MINISTÉRIO DE MINAS E ENERGIA, SECRETARIA DE GEOLOGIA, Relatório Técnico 015 "Análise das Informações Sobre Recursos Hídricos Subterrâneos no País” Mineração e Transformação Mineral-SGM. Consultor ALBERT MENTE, junho de 2009.

MMA - MINISTÉRIO DO MEIO AMBIENTE. Programa Água Doce: Documento base. 2012. Available in: http:// www.mma.gov.br/publicacoes/agua/category/41-aguadoce. Acess in: dec. 26. 2018.

NEVES, A. L. R; ALVES, M. P; LACERDA, C. F; GHEYI, H. R. Aspectos socioambientais e qualidade da água de dessalinizadores nas comunidades rurais de PentecosteCE. Revista Ambiente \& Água. v. 12, n. 1, p. 124 - 135. Available in: www.ambi-agua.net. Acess in: dec. 20. 2019. Doi: $10.4136 / 1980-993 X$

NOGUEIRA, D. Segurança hídrica, adaptação e gênero: o caso das cisternas para captação de água de chuva no semiárido brasileiro. Revista Sustentabilidade em Debate, Brasília, v. 8, n. 3, p. 22-36, dez. 2017. Available in: https://goo.gl/wB3Hvh. Acess in: dec. 17 2018. DOI: 10.18472/SustDeb.v8n3.2017.26544.

NUNES, C. C; BORGES, F, T; PRETA, M. S. F. C; BAHIA, L. M. A. Dessalinização de águas: o cenário atual brasileiro e suas projeções. Revista Vozes dos Vales - UFVJM - MG - Brasil, n. 13, Ano VII, p. 1-15, 2018. ISSN: 2238-6424. Available in: http:// www.ufvjm.edu.br/vozes. Acess in: dec. 172018.

OliveirA, J.; AlCócer, J. C. A.; XAVier, A. R. Produção de biogás a partir de biodigestores: estratégias sustentáveis para a macrorregião do Baturité massif CE. In: XAVIER, A. R.; ALCÓCER, J. C. A.; OLIVEIRA, J. Educação, ciência, tecnologia e Inovação. Fortaleza: Imprece, 2016. p. 146-162.
PEREIRA, E. R.; DEMARCHI, J. J. A. A.; BUDIÑO, F. E. L. Biodigestores- Tecnologia para o manejo de efluentes da pecuária, 2009. Available in: http://www. iz.sp.gov.br/pdfs/1255981651.pdf. Acess in: jan. 212019.

PINHEIRO, L. G.; FERREIRA, D. M.; SILVA, F. L.; MEDEIROS, J. A.; MEDEIROS, L. C.; PEIXE, P. D.; MOREIRA, S. A. Avaliação da sustentabilidade do processo de dessalinização de água no semiárido potiguar: Estudo da comunidade Caatinga Grande. Revista Sociedade \& Natureza, v.30, n.1, p.132-157, 2018. Available in: http:// www.seer.ufu.br/index.php/sociedadenatureza/article/ view/37175/pdf. Acess in: jan. 21 2019. DOI: http://dx.doi. org/10.14393/SN-v30n1-2018-6-X

PINTO, O. R. O.; ALCOCER, J. C. A.; OLIVEIRA, J.; SILVA, M. E. D.; BARBOSA, C. E. Uso do biodigestor: uma proposta sustentável na zona rural do Maciço de Baturité, Ceará. Revista Educação Ambiental em Ação, v. 65, p. 1-10, 2018. Available in: http://revistaea.org/artigo. php?idartigo=3347. Acess in: jan. 212019.

QUADROS, D. G., OLIVER, A. P.M.; REGIS, U.; VALLADARES, R. Analise econômica do biodigestor para aproveitamento dos dejetos da caprinocultura na agricultura familiar nordestino. Energia na Agricultura, Botucatu, v.30, n.1, p.1-10, 2015.

ROYA, B.; FREITAS, E.; BARROS, E.; ANDRADE, F.; PRAGANA, M.; SILVA, D. J. A. Biogás -uma energia limpa. Revista Eletrônica Novo Enfoque, ano 2011, v. 13, n. 13 , p. $142-149$.

RUOTOLO, L. A. M.; TEJEDOR-TEJEDOR, M. I.; ANDERSON, M. A. Deionização capacitiva para dessalinização de água. In: CONGRESSO BRASILEIRO DE ENGENHARIA QUÍMICA, 19 a 22, Florianópolis, 2014. Anais... Santa Catarina, 2014.

SECHINEL, A.; MENDONÇA, B.; PEGORARO, C.; FERNANDES, E.; LIMA, G.; GOMES, L.; SILVA, P.; SALGADO, R.; COMITRE, R.; OLIVEIRA, V. S. Construção de um biodigestor caseiro para obtenção de biogás e adubo. IX Simpósio de Base Experimental das Ciências Naturais da Universidade Federal do ABC - 12 e 13 de agosto de 2011.

SILVA, M. L.; ALCOCER, J. C. A.; PINTO, O. R. O.; QUEIROZ, D. M. B. Biodigestor como uma tecnologia de aproveitamento dos dejetos de suínos: Alternativa sustentável no município de Barreira, Ceará. Revista Linkscienceplace, v. 5, p. 1-15, 2018.

SILVA, N. P.; FRANCISCO, A. C. Geração de energia elétrica a partir de dejetos suínos: um estudo de caso em uma propriedade rural na região oeste do estado do Paraná. Nucleus, v.7, n.2, out. 2010 
SILVA, R. M. A. Entre o combate à seca e a convivência com o Semiárido: transições paradigmáticas e sustentabilidade do desenvolvimento. Reimp. Fortaleza: Banco do Nordeste do Brasil, 2010, 275 p.

SILVA, S. D.; MEDEIROS, V. P.; SILVA, A. B. Tecnologias sociais hídricas para convivência com o Semiárido: o caso de um assentamento rural do município de Cabaceiras PB. Revista HOLOS, v. 1, n. ano 32, p. 295-309, jan. 2016. ISSN 1807-1600. DOI: 10.15628/holos.2016.3312. Available in: http://www2.ifrn.edu.br/ojs/index.php/HOLOS/article/ viewFile/3312/1393. Acess in: dec. 152019.

SILVA, M. E. D. Políticas públicas de acesso à água e produção de alimentos: os impactos das cisternas no Município de Ibaretama, Sertão Central, Ceará. 113f. 2018. (Mestrado em Sociobiodiversidade e Tecnologias Sustentáveis) - Universidade da Integração Internacional da Lusofonia Afro-Brasileira - UNILAB, 2018.

SILVEIRA, A. P. S; DEGASPERI, F. T; ARIOVALDO, N; WLADEMIR, F. Dessalinização de águas. São Paulo: Oficina de Textos, 2015. P. 38 - 39.

SRH. Secretaria de Recursos Hídricos/ Atlas Eletrônico dos Recursos Hídricos do Ceará. Fortaleza, 2018.

SOUSA, A. B.; COSTA, C. T. F.; FIRMINO, P. R. A.; BATISTA, V.S. Tecnologias sociais de convivência com o Semiárido na região do Cariri cearense. Cadernos de Ciência \& Tecnologia, Brasília, v. 34, n. 2, p. 197-220, maio/ago. 2017. Available in: https://ainfo.cnptia.embrapa. br/digital/bitstream/item/173912/1/Tecnologias-sociais-deconvivencia-com-o-semiarido.pdf. Acess in: jan. 162019.

SOARES, T. M.; SILVA, I. J. O.; DUARTE, S. N.; SILVA, E. F. F. Destinação de águas residuárias provenientes do processo de dessalinização por osmose reversa. Revista Brasileira de Engenharia Agrícola e Ambiental, Campina Grande, v. 10, n. 3, p. 730-737, 2006.

SHUBEITA, M. F; WEBBER, T; FERNANDES, R; MARCON, C; POEHLS, B. L. Um estudo sobre monitoramento e controle de Biodigestores de pequena escala. Programa de Pós-Graduação em Ciência e Informática. PUCRS. Porto Alegre, RS, setembro de 2014.

SUIÇA. World Health Organization. Desalination for safe water supply, guidance for the heabglth and environmental aspects applicable to desalination. Genebra, 2007. Available in: http:/www.pacinst.org/ reports/desalination/desalination_report.pdf. Acess in: jan. 172019.

TOLLER, M. A. Transformação de resíduos agroindustriais através de biodigestores: uma Gestão Sócio - Ambiental. Revista Brasileira de Energias Renováveis, v.5, p. 4250, 2016.
VIEIRA, M. T.; MIRANDA, D. H.; BASQUEROTTO, C. H. C. C. Utilização do subproduto proveniente da produção de biogás como fertilizante. Revista Conexão Eletrônica - Três Lagoas, MS - Volume 13 - Número 1 - Ano 2016.

WESTRUP, G.; DUARTE, G. W.; ALBERTON, J.; NIEHUES, R. C.; ROCHA, D. A.; VANDRESEN, S. Estudo da viabilidade econômica de geração de energia elétrica a partir de biogás proveniente de dejetos de suínos de uma propriedade rural em Forquilhinha/SC. Rev. Ciênc. Cidadania - v.1, n.1, 2015.

WHO/UNICEF. 2017. Progress on Sanitation and Drinking-Water: 2017 Update. New York, WHO/ UNICEF Joint Monitoring Programme for Water Supply and Sanitation. 